\title{
The earliest fossil record of the poorly known family Condylocardiidae from Argentina
}

\author{
*Damián Eduardo Pérez ${ }^{1}$
}

\author{
${ }^{I}$ Museo Argentino de Ciencias Naturales Bernardino Rivadavia, División Paleoinvertebrados, Av. Ángel Gallardo 470 (C1405DJR), \\ Buenos Aires, Argentina. \\ trophon@gmail.com \\ *Corresponding author: trophon@gmail.com
}

\begin{abstract}
The scarcely known family Condylocardiidae (Bivalvia: Archiheterodonta) is poorly represented in the fossil record and their living representatives are also poorly known. This work presents a new representative of the family from the early Pliocene of marine terrace of Cerro Laciar (Santa Cruz Province). Carditella pitufina sp. nov. is described and characterized by a shell large for the genus, 15 radial ribs as wide as interspaces, high hinge plate and broad and large hinge teeth. The poor record of the family may be due to an identification bias, probably because the tiny size of specimens and its similarity with carditids. This new species resembles to the living Carditella tegulata from southern Argentina and Chile and they could be closely related. Carditella pitufina sp. nov. represents the most ancient record of Carditella in South America and the most ancient record of Condylocardiidae in Argentina.
\end{abstract}

Keywords: Archiheterodonta, Bivalvia, Carditella, Condylocardiidae, Patagonia, Pliocene.

RESUMEN. El registro fósil más antiguo de la poco conocida familia Condylocardiidae en Argentina. La muy poco conocida familia Condylocardiidae (Bivalvia: Archiheterodonta) está pobremente representada en el registro fósil y las especies vivientes del grupo han sido poco estudiadas. Este trabajo presenta un nuevo representante de la familia, procedente de la terraza marina de cerro Laciar (Provincia de Santa Cruz), de edad Plioceno temprano. Carditella pitufina sp. nov. es descrita y caracterizada por presentar valvas grandes para el género, 15 costillas radiales tan anchas como sus interespacios, charnela alta y ancha y dientes charnelares grandes. El pobre registro de la familia es referido a un sesgo de identificación, debido probablemente al pequeño tamaño de los especímenes y a su similaridad con los cardítidos. Esta nueva especie se asemeja a la especie viviente Carditella tegulata del extremo sur de Argentina y Chile y podrían estar estrechamente emparentadas. Carditella pitufina sp. nov. representa el registro más antiguo del género Carditella en América del Sur y el más antiguo de un Condylocardiidae para Argentina. 


\section{Introduction}

The poorly known family Condylocardiidae Bernard, 1896 is characterized by its very small size and narrow hinge with anterior and posterior lateral teeth in each valve (according to Middlefart, 2002a). Major aspects of the biology of condylocardiids are unknown (Middelfart, 2002a). Their tiny size and relative low abundance may be the reason of the scarce knowledge and recognition of living specimens. The family was related to the Carditidae and placed together in the superfamily Carditoidea (Dall, 1903a; Thiele, 1935) and recently was considered a member of the clade Archiheterodonta (Giribet, 2008). Posterior analyses of molecular sequences placed Condylocardiidae as a clade nested within Carditidae (González and Giribet, 2014). This placement agrees with the proposal of Bernard (1897) who considered the condylocardiids derived by neoteny from carditids, and Coan (2003) who suggested a polyphyletic origin for the group.

The Condylocardiidae are frequently distinguished from other archiheterodonts by their tiny size, lateral teeth in both valves, presence of internal ligament, and the presence of large prodissoconchs (Middelfart, 2002b). According other authors (Huber, 2010; Güller and Zelaya, 2013), some genera of condylocardiids present both, internal and external ligament (or exclusively external) and small prodissoconchs. These discrepancies lead to discussions about the taxonomic composition of the family (Middelfart, 2002b; Coan, 2003; Huber, 2010; Coan and Valentich-Scott, 2012).

Living Condylocardiidae were reported from Australia (Middelfart, 2002a, b), tropical eastern Pacific (Coan, 2003), eastern Atlantic (Salas and Rolán, 1990) and southern Atlantic and Pacific (Güller and Zelaya, 2013). Fossil Condylocardiidae were reported from the Paleocene of Nigeria (Adegoke, 1977); Eocene of France (Sanders et al., 2015), United States (Palmer and Brann, 1965), and New Zealand (Maxwell, 1992); Oligocene of United States (Dockery, 1982); Miocene of Australia (Tate, 1886; Ludbrook, 1953), New Zealand (Gage, 1957), Belgium (Louwye et al., 2010), Germany (Moths et al., 2010), and Indonesia (Beets, 1983); Pliocene of New Zealand (Laws, 1940), Belgium (Marquet, 2002), Trinidad and Tobago (Jung, 1969), Indonesia (Oostingh, 1935) and United States (Ward and Blackwelder, 1987); and Quaternary of South Africa (Kensley and Pether, 1986) and Costa Rica (Olsson, 1942). A possible previous record comes from the
Cretaceous of North America (Stephenson, 1941) represented by the dubious species Uddenia texana Stephenson, 1941.

There are only three fossil records of the Condylocardiidae in South America. The first is founded in the late Miocene of Uruguay (Camacho Formation) and refers to Warrana antiqua (Figueiras, 1990) (formerly described as Americuna antiqua). The second and third correspond to two mentions listed but not illustrated by Gordillo et al. (2005) from middle Holocene of Tierra del Fuego (Argentina) -Carditella naviformis (Reeve, 1843) and Carditopsis flabellum (Reeve, 1843)-. Nowadays four species of living condylocardiids are mentioned in the region, from southern Peru, Chile and Tierra del Fuego (Güller and Zelaya, 2013). The aim of this contribution is to report and to describe the most ancient fossil record of Condylocardiidae of Argentina, represented by a new species from early Pliocene marine terraces of Santa Cruz (Argentina).

\section{Geological setting}

Fossil locality of Terrace of Cerro Laciar (Fig. 1), studied by Feruglio $(1933,1950)$ and assigned to his System Terrace I, are located $50 \mathrm{~km}$ west to Puerto Deseado, Santa Cruz Province. These exposures are placed at 170-185 meters above sea level, overlaying the marine Monte León Formation (early Miocene) and consist of few meters of loose gravel with calcareous sandy matrix (Fig. 1). Condylocardiids are founded within the bivalves Scalaricardita laciarina (Feruglio, 1954), Kolmeris tehuelchana (Ihering, 1907), Ostrea ferrarisi d'Orbigny, 1842, "Chlamys" actinodes (Sowerby, 1846), and the gastropods "Trophon" varians (d'Orbigny, 1842) and Pachycymbiola feruglioi (Doello Jurado, 1931). The age of these marine fossiliferous beds has been discussed, and assigned to Miocene (Ameghino, 1906), Pliocene (Feruglio, 1950, 1954) or Pleistocene (Feruglio, 1933). Recently, Del Río et al. (2013) indicated for these deposits an early Pliocene age (5.10 $\pm 0.21 \mathrm{Ma}$, Zanclean) based on ${ }^{87} \mathrm{Sr} /{ }^{86} \mathrm{Sr}$ analysis from valves of the pectinid "Chlamys" actinodes.

\section{Material and methods}

The fossil and recent specimens used for comparisons are housed at Museo Argentino de Ciencias Naturales "Bernardino Rivadavia". Shells 


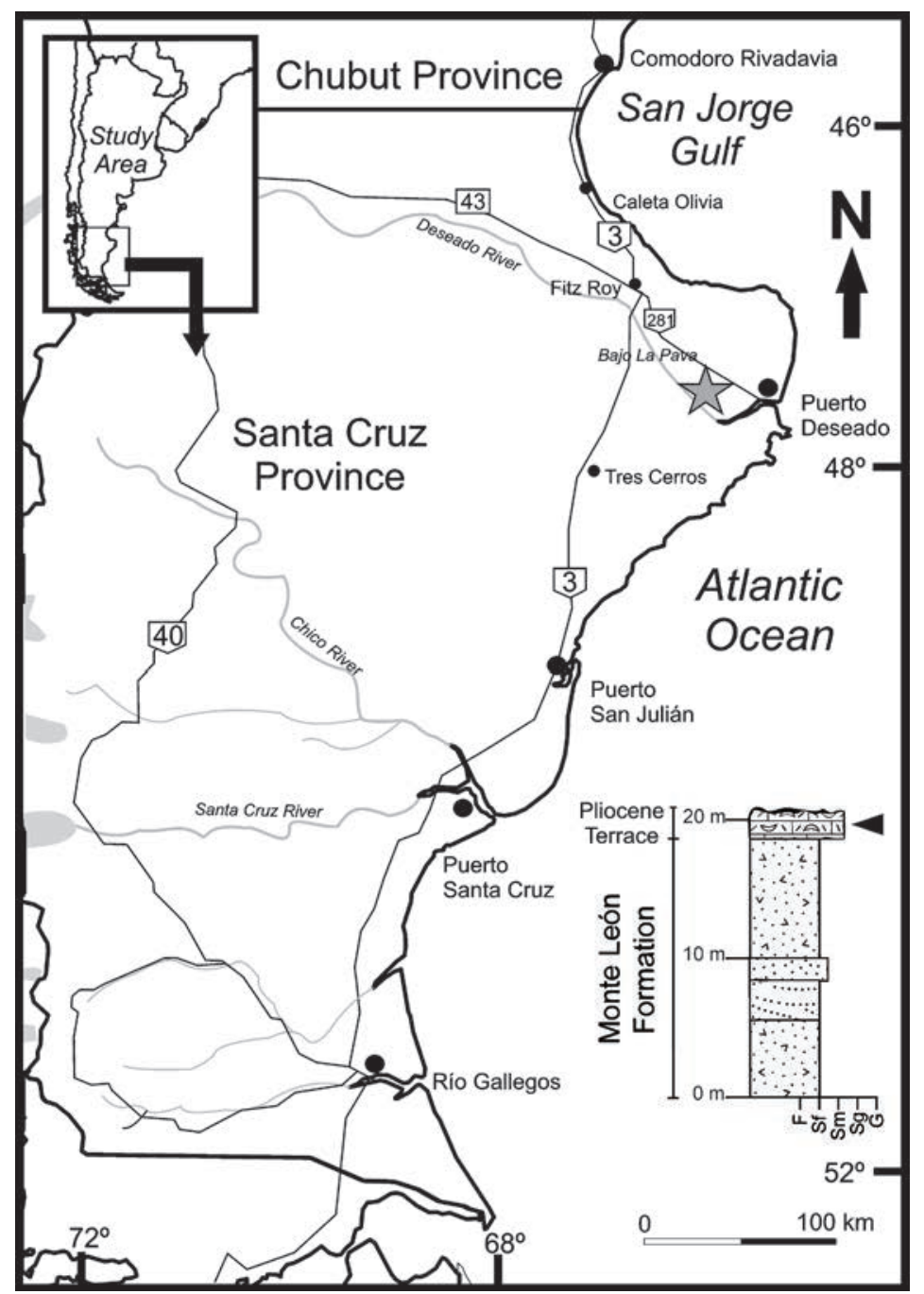

FIG. 1. Geographical provenance (indicated by a grey star) of studied fossils and lithological section at Terrace of Cerro Laciar.

were viewed with a Leika binocular magnifying glass. The preservation of fossil shells is moderate, they shows some degree of surface and edge alteration, and bioerosion product of the action of boring sponges -Entobia- (Gordillo et al., 2014). Besides, this attributes did not difficult the identification of morphological features. Hinge terminology follows Lamy (1917), other morphological terms (e.g., "ligamental pit") follows Middelfart (2002a, b).

Institutional abbreviations. MACN-In (Invertebrates Collecion of the Museo Argentino de Ciencias Naturales "Bernardino Rivadavia", Buenos Aires, Argentina); MACN-Pi (Paleoinvertebrates Collecion of the Museo Argentino de Ciencias
Naturales "Bernardino Rivadavia”, Buenos Aires, Argentina).

\section{Systematic paleontology}

\section{Order Archiheterodonta}

Family Condylocardiidae Bernard, 1896

Subfamily Carditellinae

Kuroda, Habe and Obaya, 1971

Remarks. Chavan (1969) and Middelfart (2002a, b) restricted the family for species with an external ligament only and divided the Condylocardiidae in two subfamilies: Condylocardiinae Bernard, 1896 and 
Cuninae Chavan, 1969. They placed small species with external and internal (Carditella Smith, 1881) or only external ligament (Carditellona Iredale, 1936 and Carditellopsis Iredale, 1936) within the family Carditidae, despite other characters. This approach was not followed by Coan (2003) who considered Carditella as a condylocardiid. Kuroda et al. (1971) suggested a third subfamily, Carditellinae, for these closely related species, following the original concept of Iredale and McMichael (1962) when they grouped the genera Carditellona and Carditellopsis. This approach with three subfamilies instead two was accepted by Huber (2010) and is followed here. Carditellinae taxa share with the Cuninae the presence of a small and poorly defined cup-shaped prodissoconch and triangular-shaped right middle and left posterior teeth.

\section{Genus Carditella Smith, 1881}

Type species. Carditella pallida Smith, 1881 by subsequent designation (Dall, 1903b) (Recent, southern Chile) (junior synonym of Carditella tegulata according to Güller and Zelaya, 2013).

Emended diagnosis. Shell small and flabellate. Lunule elongated. External sculpture of 11-15 radial ribs. Hinge composed by two left cardinal and three right cardinal teeth. Each valve also has two lateral teeth, one nearly marginal on the one side, the other on the opposite side being well within the outer edge, with a groove between it and the anterior margin. External and internal ligament small, internal placed beneath the apex of the valves in a small resilifer (Modified from Smith, 1881).

Remarks. In its original description, Smith (1881) recognized that external sculpture resembles carditids. The genus Carditella is characterized by their flabellate shell-outline with wide radial ribs covered by subrectangular nodes, hinge with two left and three right cardinal teeth and anterior and posterior lateral teeth in both valves. Also, Carditella has external and internal ligament, the latter marked by a ligamental pit beneath the apex in left valve. The presence of strongly developed lateral teeth and a small ligamental pit allow to place the new species in the condylocardiid genus Carditella. Hinge configuration and external sculpture do not differ from other species of Carditella.

Two fossil species of Carditella were recorded: C. baloguni Adegoke, 1977 (late Paleocene, Nigeria) and C. aldrichi (Casey, 1903) (middle Eocene-early Oligocene, United States of America). Carditella calipsamma Carrington and Kensley, 1969 (late Pliocene-early Pleistocene, South Africa) seems to be a representative of the genus Carditellona Iredale, 1936 instead a southern African Carditella species. Nowadays, the genus Carditella is represented by $C$. naviformis (Reeve, 1843) (southern South America), C. tegulata (Reeve, 1843) (southern Peru to Tierra del Fuego), C. semen (Reeve, 1843) (southern Peru to Chile), C. exulata Smith, 1885 (Tristan da Cunha), C. galapagana Coan, 2003 (western coast of Colombia and Galapagos Islands), C. marieta Coan, 2003 (western coast of Mexico), C. capensis Smith, 1885 (Recent, Angola and South Africa), C. delli Crozier, 1966 (northern New Zealand), C. iejimensis Hayami and Kase, 1993 (southern Japan), C. laticosta Smith, 1904 (South Africa), C. mawsoni Dell, 1972 (Weddel Sea), and C. tridacnula Oliver and Chesney, 1997 (Oman).

\section{Carditella pitufina sp. nov. Fig. 2.1-13, 3.1}

Etymology. The specific epithet refers to the Belgian comic characters created by Peyo, "Les Schtroumpfs" (called "The Smurfs" in English and "Los Pitufos" in Spanish speaker countries). These creatures are characterized by their tiny sizes as the condylocardiids bivalves. This epithet is expressed in Spanish diminutive form to emphasize the reference.

Type material. Holotype MACN-Pi 6344 (a left valve). Paratype MACN-Pi 6344 (a left and three right valves).

Type locality and horizon. Terrace of Cerro Laciar, Santa Cruz Province (lower Pliocene marine terraces).

Diagnosis. Shell large for the genus (length range 6.27-7.12 mm), external sculpture of 15 radial ribs as wide as interspaces, hinge plate high and hinge teeth broad and large.

Description. Shell large-sized for the genus (length range 6.27-7.12 mm) (Table 1), mainly subtriangular; convex anterior and posterior margins, rounded ventral margin, dorsal margin sharply sloping and very curved, angle between dorsal and posterior margins smooth, angle between dorsal and anterior margins weak marked. Umbo small, pointed or slightly rounded, anteriorly directed, placed at centre to anterior third of the valve length. Lunule large, 
elongated and narrow, slightly concave, without sculpture and smoothly separated from remaining surface of shell. Escutcheon large and elongated, smooth, larger than lunule. Prodissoconch small, eroded in all specimens studied. Hinge plate high, three cardinal and two lateral teeth in right valve and two cardinal and two lateral teeth in left valve. Right valve hinge with rounded ventral edge; anterior cardinal tooth thin and straight, anteriorly inclined; middle cardinal tooth subtriangular, slightly inclined posteriorly, with broad base; posterior cardinal tooth thin, long and straight; anterior lateral tooth elongated, wide, separated from lunular margin; posterior lateral tooth elongated, high, not differentiated from anterior margin. Left valve hinge with a straight ventral edge; anterior cardinal tooth curved, anteriorly inclined, with broad base; posterior cardinal tooth long and curved, inclined posteriorly, with broad base and acute apex; anterior lateral tooth thin and high, close to anterior margin; posterior lateral tooth long and wider than anterior lateral. Small ligamental pit placed below beak in left hinge. External sculpture of 15 radial ribs as wide as interspaces, with subrectangular transverse section, covered by rectangular nodes; interspaces with subrectangular transverse section. Pallial line at a quarter of total valve height. Inner ventral margin crenulated; crenulations subrectangular and truncated, covering the entire margin.
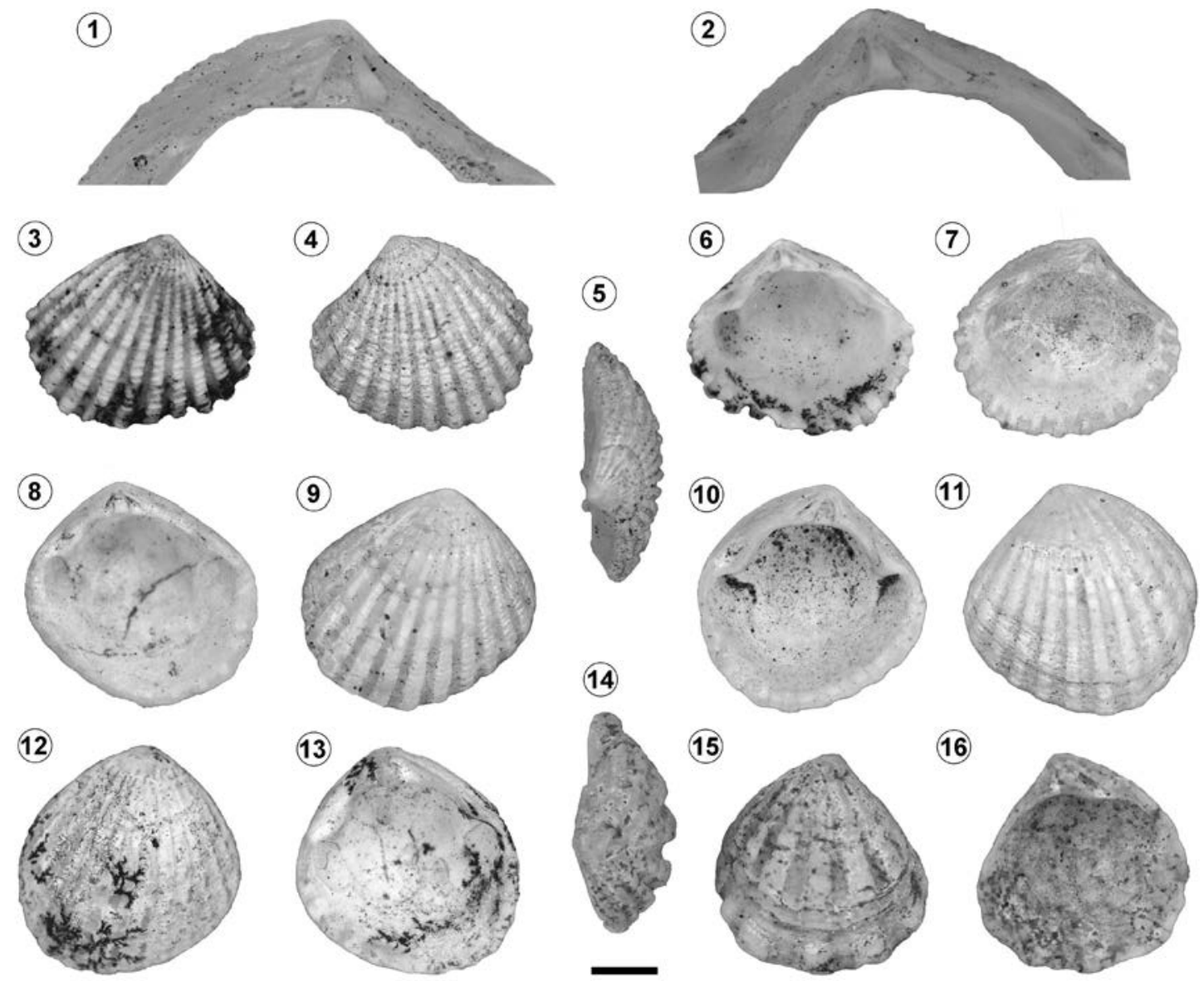

(15)

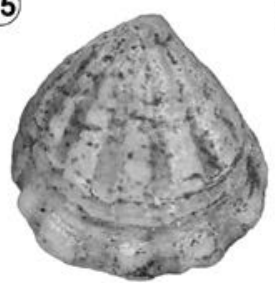

(16)

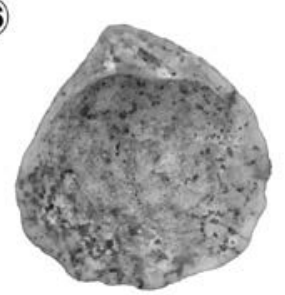

FIG. 2. 1-13. Carditella pitufina n. sp., MACN-Pi 6344; 1. Left hinge (Holotype); 2. Right hinge (Paratype); 3. Right valve, lateral view (Paratype); 4. Left valve, lateral view (Holotype); 5. Left valve, dorsal view (Holotype); 6. Right valve, internal view (Paratype); 7. Left valve, internal view (Holotype); 8. Right valve, internal view (Paratype); 9. Right valve, lateral view (Paratype); 10. Left valve, internal view (Paratype); 11. Left valve, lateral view (Paratype); 12. Right valve, lateral view (Paratype); 13. Right valve, internal view (Paratype); 14-16. Kolmeris tehuelchana (Ihering, 1907), MACN-Pi 2214; 14. Right valve, dorsal view; 15. Right valve, lateral view; 16. Right valve, internal view. Scale bar represents $5 \mathrm{~mm}$ for 1-2, and $2 \mathrm{~mm}$ for 3-16. 
TABLE 1. MEASUREMENTS OF STUDIED SPECIMENS OF CARDITELLA PITUFINA SP. NOV.

\begin{tabular}{ccc}
\hline Specimen & $\begin{array}{c}\text { Length } \\
(\mathbf{m m})\end{array}$ & $\begin{array}{c}\text { Height } \\
(\mathbf{m m})\end{array}$ \\
\hline MACN-Pi 6344-1 (Paratype) & 7.04 & 6.8 \\
MACN-Pi 6344-2 (Paratype) & 6.27 & 6.03 \\
MACN-Pi 6344-3 (Paratype) & 6.91 & 6.79 \\
MACN-Pi 6344-4 (Paratype) & 6.63 & 6.44 \\
MACN-Pi 6344-5 (Paratype) & 6.8 & 7.01 \\
MACN-Pi 6344-6 (Holotype) & 6.85 & 6.06 \\
MACN-Pi 6344-7 (Paratype) & 7.12 & 6.17 \\
\hline
\end{tabular}

Remarks. Shell of the new species shows some variability from more to less triangular outlines. Placement of umbos is more or less centrally. Development of shell margins and radial ribs varying in studied specimens but they are due to taphonomic processes (e.g., surface alteration).

This new species strongly resembles to Carditella tegulata (Reeve, 1843) (Recent, Valparaíso [33 $\mathrm{S}$ ]

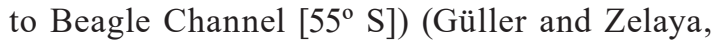
2013: Fig. 5) but is distinguished by its quite larger shell with narrower radial ribs, higher hinge plates, larger and broader cardinal teeth, and right hinge with less curved middle tooth. Also, the dorsal margin in the fossil species is more curved and the prodissoconch is smaller than those of C. tegulata. On the other hand, the new species can be distinguished from C. baloguni Adegoke, 1977 (Ewekoro Formation, late Paleocene, Nigeria) (Adegoke, 1977: pl. 50, Figs. 1-7) by its less prominent umbos, broader hinge and less numerous radial ribs without comarginal nodes.

Carditella pitufina sp. nov. resembles C. aldrichi (Casey, 1903) (Gosport Sand, Mint Spring and Byram formations, middle Eocene-early Oligocene, United States of America) (Dockery, 1982; pl. 24, figs. 1213, pl. 25, figs. 1-5, 7) but the Argentinean species has a less elongated shell, less rounded posterior margin, and broader hinge with less divergent and more robust teeth.

Carditella pitufina sp. nov. can be separated from C. naviformis (Reeve, 1843) (Recent, Valparaíso $\left[33^{\circ} \mathrm{S}\right]$ to Malvinas Islands [51 $\left.{ }^{\circ} \mathrm{S}\right]$ ) (Güller and Zelaya, 2013, fig. 6) and C. semen (Reeve, 1843) (Recent, Isla Lobos de Afuera, Peru [ $\left.7^{\circ} \mathrm{S}\right]$ to Isla Blanca, Chile $\left[27^{\circ} \mathrm{S}\right]$ ) (Güller and Zelaya, 2013:
Fig. 7) because the expanded outlines in the living species, with the presence of a more prominent prodissoconch separated from teleoconch by a bulging rim, fine comarginal lines between radial ribs, and with smaller and narrower hinge teeth.

\section{Discussion}

There are very few previous records of the family Condylocardiidae in South America (Figueiras, 1990; Gordillo et al., 2005), which may be due to an identification bias. Shells of this group are very small sized (see Table 1 for Carditella pitufina sp. nov. sizes), and hinge features are visible only by magnification. Small bivalves are difficult to assign taxonomically (Valentine et al., 2006). Externally, condylocardiids resemble to small specimens of Carditidae taxa, and Smith (1881) already mentioned the external similarity between Carditella and carditids. At the marine terraces of Cerro Laciar, two small carditid species are recorded: Kolmeris tehuelchana (length range of 6.3-15.9 mm) (Fig. 2.14-16, Fig. 3.2, 3.4) and Scalaricardita laciarina (length range of 8.4-26 mm) (Fig. 3.3), but differences on adult size among them are noticeable (Fig. 3). Carditid species share external sculpture of radial ribs with Carditella pitufina sp. nov., but they present 25-27 (S. laciarina) or 13-15 ribs stacked at sides (K. tehuelchana) (Pérez and Del Río, 2017), while the condylocardiid has 15 not stacked radial ribs. In S. laciarina, radial ribs are covered by subrectangular nodes as in C. pitufina sp. nov., but in K. tehuelchana, radial ribs are smooth (Pérez and Del Río, 2017). Also, carditids have not lateral teeth or ligamental pit. These features distinguish the new species from the known carditids of the Cerro Laciar marine terraces. Some juvenile specimens of $K$. tehuelchana with similar size of adult C. pitufina sp. nov. present these strong differences in hinge teeth and external sculpture (Fig. 2.15). Specimens of $C$. pitufina sp. nov. here described were founded among very small Carditidae specimens originally collected by E. Feruglio.

Pleuromeris Conrad, 1867 is another small carditid genus recorded in the late Oligocene-middle Miocene of Argentina (San Julián, Monte León and Carmen Silva formations). This genus is represented by two species, $P$. sulcolunularis (Ihering, 1907) and P. fueguina (Steinmann and Wilckens, 1908). Pleuromeris is characterized by small (less than 

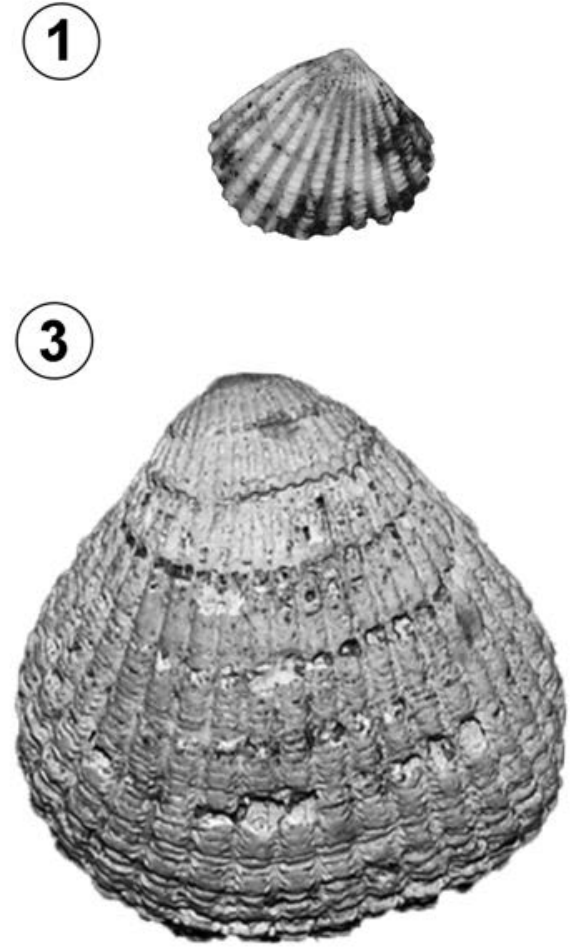
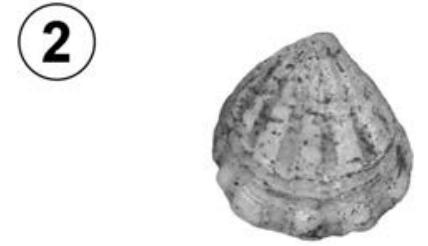

(4)

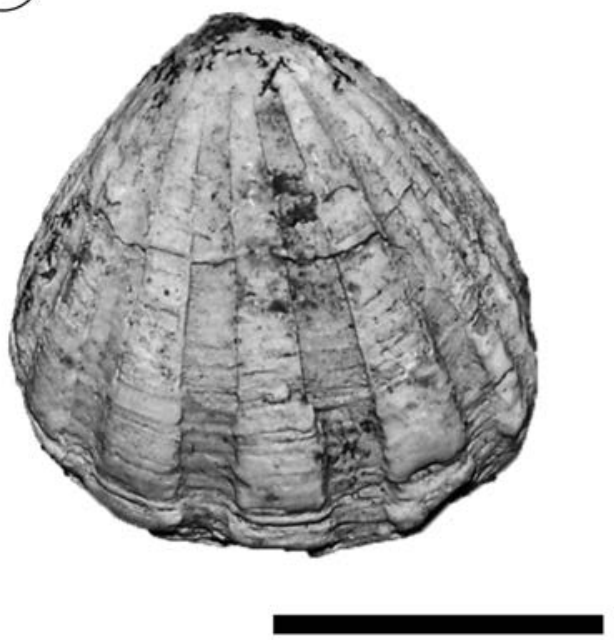

FIG. 3. Comparison between Carditella pitufina n. sp. and carditids of Terrace of Cerro Laciar. 1. Carditella pitufina n. sp., MACNPi 6344, right valve, lateral view (Paratype); 2. Juvenile Kolmeris tehuelchana (Ihering, 1907), MACN-Pi 2214, right valve, lateral view; 3. Adult Scalaricardita laciarina (Feruglio, 1954), MACN-Pi 2213, left valve, lateral view; 4. Adult Kolmeris tehuelchana (Ihering, 1907), MACN-Pi 361, left valve, lateral view. Scale bar represents $10 \mathrm{~mm}$.

$30 \mathrm{~mm}$ in length) and subtriangular outlined shells. This taxon has a broad and triangular right middle tooth and a reduced left anterior tooth that are not present in Carditella. Also, the condylocardiid genus has lateral teeth in both hinges. Some small species of Pleuromeris from New Zealand (e.g., P. benthicola, P. ultima) externally resemble to Carditella but they have wider radial ribs and a broader right middle tooth. Argentinian species of Pleuromeris have larger shells (near to $20-25 \mathrm{~mm}$ ), broad right middle tooth and a higher number of radial ribs.

Carditella was present in the Paleocene of Africa and in the Oligocene-Eocene of North America, but this is its first Pliocene record. The present distribution of Carditella ranges from southern South America towards Pacific coast to Colombia and Mexico, and by Atlantic coast towards southern Africa. The genus is also present in New Zealand, Japan and Oman.
The species of Condylocardiidae from the southern South America are distributed from Tierra del Fuego towards Chile and Peru, and they are represented by four species: Carditella tegulata (Reeve, 1843), C. naviformis (Reeve, 1843), C. semen (Reeve, 1843) and Carditopsis flabellum (Reeve, 1843) (Güller and Zelaya, 2013). The new record of C. pitufina sp. nov. indicates a more northern distribution of the group in western Atlantic for Pliocene times, and the most ancient record of the genus in South America. Carditella pitufina sp. nov. is very similar to the Recent $C$. tegulata, which is recorded from middle Holocene (Gordillo et al., 2005), and could be a Pliocene relative for this species.

Pliocene marine terraces of Argentina were recently recognized because their debated age (Del Río et al., 2013), the faunal composition of Terrace of Cerro Laciar was not revised after Feruglio (1933, 
1950, 1954), notwithstanding some mentions (Del Río and Martínez, 2006; Aguirre et al., 2008; Pérez and Del Río, 2017; Trovant et al., 2017). In contrast of Miocene molluscs of Patagonia (Martínez and Del Río, 2002; Del Río et al., 2010), Pliocene molluscs seems to be more related to actual malacological faunal composition. According to the faunal list provided by Feruglio (1950) (and the previously mentioned posterior revisions), Terrace of Cerro Laciar includes a certain amount of extant taxa [e.g., Mactra isabelleana d'Orbigny, 1846, Mytilus edulis Linnaeus, 1758, Perumytilus purpuratus (Lamarck, 1819), Tegula patagonica (d'Orbigny, 1835), Trochita pileolus (d'Orbigny, 1842), Falsilunatia patagonica (Philippi, 1845), Trophon geversianus (Pallas, 1774), "Trophon" varians (d'Orbigny, 1842), Boreoscala magellanica (Philippi, 1845)] and other taxa closely related to extant species [e.g., Amiantis laziarina (Ihering, 1903), "Chione" laciarina Feruglio, 1954, Urosalpinx sp., Pachycymbiola feruglioi (Doello Jurado, 1931)]. The new record of Carditella are placed in the second group, and enriches the connections between Pliocene and modern faunas. New revisions of this mollusc fauna are needed for enlighten the origins of modern faunal composition of southern South America.

\section{Conclusions}

A new species of the genus Carditella Smith, 1881, C. pitufina sp. nov., is described from the early Pliocene marine terraces of Cerro Laciar, Santa Cruz Province, Argentina. This finding represents the most ancient fossil record of Condylocardiidae of Argentina and the most ancient record of the genus Carditella for the south end of South America.

\section{Aknowledgements}

Thanks to the curators M. Longobucco (MACNPi), C. Del Río (MACN-Pi) and A. Tablado (MACNIn). Thanks to M. Belén Santelli (MACN-Pi) who suggested the idea of the specific name for the new taxa and M. Álvarez (MACN-Pi) for his suggestions. I am very grateful to P. Hanisch (MACN) for her help with the photography of very small shells. Also thank to M. Güller (MACN) for helping in the very preliminary stage of this research and the workers of the Library of MACN for their valuable assistance.

\section{References}

Adegoke, O. 1977. Stratigraphy and Paleontology of the Ekeworo Formation (Paleocene) of southwestern Nigeria. Bulletin of American Paleontology 71 (295): 1-379.

Aguirre, M.; Hlebszevitsch Savalscky, J.; Dellatorre, F. 2008. Late Cenozoic invertebrate paleontology of Patagonia and Tierra del Fuego, with emphasis on molluscs. Developments in Quaternary Science 11: 285-325.

Ameghino, F., 1906. Les formations sédimentaires du Crëtacé supérieur et du Tertiaire de patagonie. Anales de Museo Nacional Buenos Aires 3 (8): 1-568.

Beets, C. 1983. Miocene mollusks from Muara Kobun and Pulu Senumpah, Sangkulirang Bay, northern Kutai (East Borneo). Scripta Geologica 67: 1-21.

Bernard, F. 1896. Diagnoses de coquilles nouvelles de lamellibranches (Genres Hochstetteria et Condylocardia). Bulletin de Muséum National d'Histoire Naturelle 2 (5): 193-197. Paris.

Bernard, F. 1897. Etudes comparatives sur la coquille des lamellibranches Condylocardia. Journal de Conchyliogie 46 (3): 169-207.

Carrington, A.; Kensley, B. 1969. Pleistocene molluscs from the Namaqualand coast. Annals of the South African Museum 52 (9): 189-223.

Casey, T. 1903. Notes on the Conrad collection of Vicksburg fossils, with descriptions of new species. Proceedings of the National Academy of Sciencies of Philadelphia 55: 261-283.

Chavan, A. 1969. Superfamily Carditacea Fleming, 1920. In Treatise on Invertebrate Paleontology, Part N, Mollusca 6, Bivalvia, volumen 2 (Moore, R.C.; editor.). Geological Society of America and The University of Kansas: 543-561. Lawrence.

Coan, E. 2003. The tropical eastern Pacific species of the Condylocardiidae (Bivalvia). The Nautilus 117 (2): 47-61.

Coan, E.V.; Valentich-Scott, P.H. 2012. Bivalve seashells of tropical West America: marine bivalve mollusks from Baja California to northern Perú. Santa Barbara Museum of Natural History, Monographs 6: 1-1223.

Conrad, T.A. 1867. Description of a new genus of Astartidae. American Journal of Conchology 3: 191.

Crozier, M. 1966. New species and records of Mollusca from off the Three Kings Islands, New Zealand. Transactions of the Royal Society of New Zealand, Zoology 8: 39-49.

Dall, W.H. 1903a. Contributions to the Tertiary fauna of Florida with special reference to the Silex Beds of 
the Caloosahatchie River. Part IV. Transactions of the Wagner Free Institute of Science of Philadelphia 3 (4): 1219-1654.

Dall, W.H. 1903b. Synopsis of the Carditacea and of the American species. Proceedings of the Academy of Natural Sciences of Philadelphia 54: 696-719.

Dell, R. 1972. Notes on nomenclature of some Mollusca from Antarctica and southern South America. Records of the Dominion Museum 8: 21-42.

Del Río, C.J.; Martínez, S. 2006. The family Volutidae (Mollusca-Gastropoda) in the Tertiary of Patagonia (Argentina). Journal of Paleontology 80 (5): 919-945.

Del Río, C.J.; Martínez, S.; Orensanz, J. 2010. Tertiary roots in the Recent Molluscan faunas of the Southwestern Atlantic Ocean. In International Paleontological Congress, No. 3, Abstracts: p. 140. London.

Del Río, C.J.; Griffin, M.; McArthur, J.; Martínez, S.; Thirlwall, M. 2013. Evidence for early Pliocene and late Miocene transgressions in southern Patagonia (Argentina): ${ }^{87} \mathrm{Sr} /{ }^{86} \mathrm{Sr}$ ages of pectinid "Chlamys" actinodes (Sowerby). Journal of South American Earth Sciences 47: 220-229.

Dockery, D. 1982. Lower Oligocene Bivalvia of the Vicksburg Group in Mississippi. Mississippi Department of Natural Resources Bureau of Geology 123: 1-261.

Doello Jurado, M. 1931. Una nueva especie de Voluta fósil de Patagonia. Anales del Museo Nacional de Historia Natural Bernardino Rivadavia 36: 503-513.

d'Orbigny, A. 1842. Voyage dans l'Amerique meridionale (Le Brasil, l'Uruguay exsecuté pendant les anné 18261833. Paleontologie et Geologie 3: 1-187.

d'Orbigny, A. 1835-1846. Voyage dans l'Amerique meridionale (Le Brasil, l'Uruguay exsecuté pendant les anné 1826-1833). Mollusques 5 (3): 1-758, pl. 1-85. Paris.

Feruglio, E. 1933. I terrazzi marine della Patagonia. Giornale di Geologia 8: 1-288.

Feruglio, E. 1950. Descripción Geológica de la Patagonia, Tomo 3: p. 431. Buenos Aires.

Feruglio, E. 1954. Alcune nuove forme di brachiopodi e molluschi del Terziario e Cretaceo superiore della Patagonia. Pubblicazioni dell'Instituto Geologico della Universitá di Torino 2: 1-45.

Figueiras, A. 1990. Nueva especie fósil de Americuna Klappenbach. 1963 (Mollusca: Bivalvia: Condylocardiidae) del Mioceno Superior de Uruguay. Comunicaciones de la Sociedad Malacológica de Uruguay 7 (58-59): 165-173.
Gage, M. 1957. The Geology of the Waitaki Subdivision. New Zealand Geological Survey, Bulletin 55: 1-135.

Giribet, G. 2008. Bivalvia. In Phylogeny and Evolution of the Mollusca (Ponder, W.F.; Lindberg, D.R.; editors). University of California Press: 105-141. Berkeley.

González, V.L.; Giribet, G. 2014. A new cryptic species of carditid bivalve from the Gulf of California (Mollusca, Bivalvia, Archiheterodonta, Carditidae). Malacología 55: 235-250.

Gordillo, S.; Coronato, A.; Rabassa, J. 2005. Quaternary molluscan faunas from the island of Tierra del Fuego after the Last Glacial Maximum. Scientia Marina 69 (Suppl. 2): 337-348.

Gordillo, S.; Bayer, M.S.; Boretto, G.; Charó, M. 2014. Mollusks Shells as bio- geo-archives. Springer Briefs in Earth System Sciences: 80 p. London.

Güller, M.; Zelaya, D.G. 2013. The families Carditidae and Condylocardiidae in the Magellan and Peru-Chile provinces (Bivalvia: Carditoidea). Zootaxa 3682: 201-239.

Hayami, I.; Kase, T. 1993. Submarine cave Bivalvia from the Ryukyu Islands: systematics and evolutionary significance. The University Museum, The University of Tokyo, Bulletin 35: 1-133.

Huber, M. 2010. Compendium of bivalves. A full-color guide to 3.300 of the world's marine bivalves. A status on Bivalvia after 250 years of research. ConchBooks, Hackenheim: 901 p.

Ihering von, H. 1903. Les Mollusques des Terrains Crétaciques Supérieurs de l'Argentine Orientale: Anales del Museo Nacional de Buenos Aires, serie 3 (2): 193-229.

Ihering von, H. 1907. Les Mollusques fossiles du Tertiaire et du Crétacé supérieur del' Argentine. Anales del Museo Nacional de Buenos Aires, serie 3 (7): 1-611.

Iredale, T. 1936. Australian molluscan notes, No. 2. Records of the Australian Museum 19 (5): 267-340.

Iredale, T.; McMichael, D. 1962. A reference list of the marine Mollusca of New South Wales. Australian Museum, Memoir 11: 1-109.

Jung, P. 1969. Miocene and Pliocene mollusks from Trinidad. Bulletins of American Paleontology 55: 289-657.

Kensley, B.; Pether, J. 1986. Late Tertiary and Early Quaternary Fossil Mollusca for the Hondeklip Area, Cape Province, South Africa. Annals of the South African Museum 97 (6): 141-225.

Kuroda, T.; Habe, T.; Obaya, K. 1971. The sea shells of Sagami Bay. Tokyo, Maruzen: 489 p.

Lamarck, J.-B.M. de. 1819. Histoire naturelle des animaux sans vertèbres. Tome sixième, 1re partie. Paris: published by the Author: $343 \mathrm{p}$. 
Lamy, M. 1917. Révision des Crassatellidae vivants du Muséum D’Histoire Naturelle de Paris. Journal de Conchyliologie 62 (4): 197-270.

Laws, C. 1940. Palaeontological Study of Nukumaruan and Waitotaran Rocks near Wanganui. Transactions and Proceedings of the Royal Society of New Zealand 70: $34-56$.

Linnaeus, C. 1758. Systema naturae per regna tria naturae. Editio decima, reformata 1 (Regnum animale). Stockholm (Salvii): 824 p.

Louwye, S.; Marquet, R.; Bosselaers, M.; Lambert, O. 2010. Stratigraphy of an early-middle Miocene sequence near Antwerp in Northern Belgium (Southern North Sea Basin). Geologica Belgica 13 (3): 269-284.

Ludbrook, N.H. 1953. The molluscan fauna of the Pliocene strata underlying the Adelaide Plains. Part 1. Transactions of the Royal Society of South Australia 77: 42-64.

Marquet, R. 2002. The Neogene Amphineura and Bivalvia (Protobranchia and Pteriomorphia) from Kallo and Doel (Oost Vlaanderen, Belgium). Palaeontos 2: 1-100.

Martínez, S.; Del Río, C.J. 2002. Late Miocene molluscs from the southwestern Atlantic Ocean (Argentina and Uruguay): a palaeobiogeographic analysis. Palaeogeography, Palaeoclimatology, Palaeoecology 188: 167-187.

Maxwell, P.A.1992. Eocene Mollusca from the vicinity of McCulloch's Bridge, Waihao River, South Canterbury, New Zealand: Paleoecology and systematics. New Zealand Geological Survey, Paleontological Bulletin 65: $1-280$.

Middelfart, P. 2002a. A revision of the Australian Condylocardiinae (Bivalvia: Carditoidea: Condylocardiidae). Molluscan Research 22 (1): 23-85.

Middelfart, P. 2002b. Revision of the Australian Cuninae sensu lato (Bivalvia: Carditoidea: Condylocardiidae). Zootaxa 112: 1-124.

Moths, H.; Albrecht, F.; Stein, G. 2010. Die molluskenfauna (Hermmorium, Untermiozän) aus der Kiesgrube kirnke bei Werder (Nordwest-Niedersachsen). Palaeofocus 3: 1-155.

Oliver, P.; Chesney, H. 1997. Taxonomy and descriptions of bivalves (Lucinoidea, Galeommatoidea, Carditoidea, Cardioidea, Tellinoidea \& Myoidea) from the Arabian Sea. Journal of Conchology 36 (1): 51-76.

Olsson, A.A. 1942. Tertiary and Quaternary fossils from Burica Peninsula of Panama and Costa Rica. Bulletins of American Paleontology 27 (106): 1-106.
Oostingh, C. 1935. Die Mollusken des Pliozäns von Boemiajoe (Java). Dienst van den Mijnbouw in Nederlandsch-Indië Wetenschappelijke Mededeelingen 26: 1-247.

Pallas, P.S. 1774. Spicilegia Zoologica, quibus novae imprimis et obscurae animalium species iconibus, descriptionibus atque commentariis illustrantur cura. Fasciculus 10: 1-41.

Palmer, K.V; Brann, D.C. 1965, Catalogue of the Paleocene and Eocene Mollusca of the Southern and Eastern United States. Part I. Pelecypoda, Amphineura, Pteropoda, Scaphopoda, and Cephalopoda. Bulletin of American Paleontology 48: 1-467.

Pérez, D.; Del Río, C. 2017. Systematics of the family Carditidae (Bivalvia: Archiheterodonta) in the Cenozoic of Argentina. Zootaxa 4338 (1): 51-84.

Philippi R. 1845. Diagnosen einiger neuen Conchylien. Archiv für Naturgeschichte 11: 50-71.

Reeve, L.A. 1843. Conchologia Iconica. London: 17 p.

Salas, C.; Rolán, E. 1990. Four new species of Condylocardiidae from Cape Verde Islands. Bulletin du Museum National d'Histoire Naturelle Section A Zoologie Biologie et Ecologie Animales 12 (2): 349-364. Paris.

Sanders, M.; Merle, D.; Villier, L. 2015. The molluscs of the "Falunière" of Grignon (Middle Lutetian,Yvelines, France): quatification of lithification bias and its impact on the biodiversity assessment of the Middle Eocene of Western Europe. Geodiversitas 37 (3): 345-365.

Smith, E.A. 1881. Mollusca and Molluscoida. In Zoological Collection made during the Survey of H.M.S. "Alert" (Gunther, A.; editor). Zoological Society of London: 22-44.

Smith, E.A. 1885. Report on the Lamellibranchiata collected by H.M.S. "Challenger" during the years 1873-1876. Reports of the scientific results of the voyage of H.M.S. "Challenger”. Zoology 13 (35): 1-341.

Smith, E.A. 1904. On a collection of marine shells from Port Alfred, Cape Colony. Journal of Malacology 11 (2): 21-44.

Sowerby, I.G.B. 1846. Description of the Tertiary fossils shells from South America. In Geological Observations on the volcanics Islands and parts of South America visited during the voyage of H.M.S. "Beagle" (Darwin, C.; editor). Appleton. London: 249-264.

Steinmann, G.; Wilckens, O. 1908. Kreide und Tertiärfossilien aus den Magellansländern, gesammelt von der Schwedischen Expedition 1895-1897. Arkiv für Zoologi 4: 1-119. 
Stephenson, L. 1941. The larger invertebrate fossils of the Navarro Group of Texas. The University of Texas Publication 4101: 1-855.

Tate, R. 1886. The lamellibranchs of the Older Tertiary of Australia (part 1). Transactions of the Royal Society of South Australia 8: 96-158.

Thiele, G. 1935. Handbuch der systematischen Weichtierkunde. Teil 3: 779-1022.

Trovant, B.; Márquez, F.; Del Río, C.; Ruzzante, D.; Martínez, S.; Orensaz, J. 2017. Insights on the history of the scorched mussel Brachidontes rodriguezii (Bivalvia:
Mytilidae) in the Southwest Atlantic: a geometric morphometric. perspective Historical Biology 30 (4): 564-572. doi: 10.1080/08912963.2017.1306699. Valentine, J.; Jablonski, D.; Kidwell, S.; Roy, K. 2006. Assessing the fidelity of the fossil record by using marine bivalves. Proceedings of the National Academy of Sciences 103 (17): 6599-6604.

Ward, L.; Blackwelder, B. 1987. Late Pliocene and Early Pleistocene Mollusca from the James City and Chowan River Formations at Lee Creek Mine. Smithsonian Contributions to Paleobiology 61: 113-283.

Manuscript received: December 07, 2017; revised/accepted: September 13, 2018; available online: February 04, 2019. 